\title{
FOLDS TRENDING AT VARIOUS ANGLES TO THE TRANSPORT DIRECTION IN THE MARCQ AREA, BRABANT MASSIF, BELGIUM
}

\author{
Timothy DEBACKER
}

(11 figures and 1 table)

\begin{abstract}
University of Gent, Department of Geology and Pedology, Krijgslaan 281, S8, B-9000 Gent. timothy.debacker@rug.ac.be
\end{abstract}

\begin{abstract}
Generally folds in fold belts are expected to trend approximately parallel to the main axis of the fold belt. Indeed, most of the fold hinge lines along the southern rim of the poorly exposed Lower Palaeozoic Brabant Massif reflect the general trend of the massif (transverse folds). However, in some places, folds exist oriented at high angles to the general trend of the massif (longitudinal folds).

New field work in the Marcq area, situated in the southwestern part of the Brabant Massif, reveals the presence of transverse, longitudinal and oblique asymmetric folds. Direct field observations, combined with borehole and geophysical data, indicate the presence of a low-angle high-strain zone, interpreted as a reverse shear zone. The various fold orientations are explained by means of differential movement within this shear zone. All the structural features are considered to be the result of one single progressive deformation.

Although this shear zone is probably of minor regional significance, the kinematic inferences made in the Marcq area may have important implications for the outline of the overall tectonic image of the southwestern part of the Brabant Massif.
\end{abstract}

KEYWORDS: Brabant Massif, differential displacement, shear zone, structural geology

\section{Introduction}

The poorly exposed Brabant Massif forms the southernmost part of the Anglo-Brabant fold belt. The Brabant Massif consists of Lower Cambrian to upper Silurian sediments, overlain with an angular unconformity by Middle Devonian (Givetian) sediments. At present there is only clear evidence for one major deformation phase, acting on the Brabant Massif from the Early to early Middle Devonian (Van Grootel et al., 1997). Since the timing of this deformation phase is largely synchronous with the Acadian Orogeny in the Northern Appalachians, this phase is also referred to as Acadian in the Irish, British and Belgian parts of the Anglo-Brabant fold belt (cf. Soper et al., 1987, Van Grootel et al., 1997).

The outcrop areas are situated in the southern part of the massif. There, both the cleavage and the fold hinge line patterns describe a broad apparent arc shape, concave to the north (Fourmarier, 1914, Fourmarier, 1921,
Sintubin, 1997). In the SE-parts (e.g. Mehaigne area) the cleavage and fold hinge line patterns are oriented ENE-WSW, whereas in the SW-parts (e.g. SenneSennette area, Dyle-Thyle area) the cleavage and fold hinge line patterns are oriented WNW-ESE to NW-SE (fig. 1). In both areas the folds generally have a Sverging asymmetry with subhorizontal to gently plunging fold hinge lines and are cut by a cogenetic steeply $\mathrm{N}$-dipping cleavage (Sintubin, 1997). Depending on the relative orientation of the cleavage and the folds, the cleavage may be axial planar to the folds or, more common, axially transects the folds (fig. 1). Although in the southwestern outcrop areas most of the fold hinge lines are oriented approximately parallel to the general trend of the fold belt (NW-SE), Fourmarier (1914) came across folds trending at a high angle to the overall structural trend (e.g. Marcq area). Due to the lack of orientation measurements, the limited number of exposures and the poorly defined stratigraphy, the particular orientation of these folds has never been fully explained. 


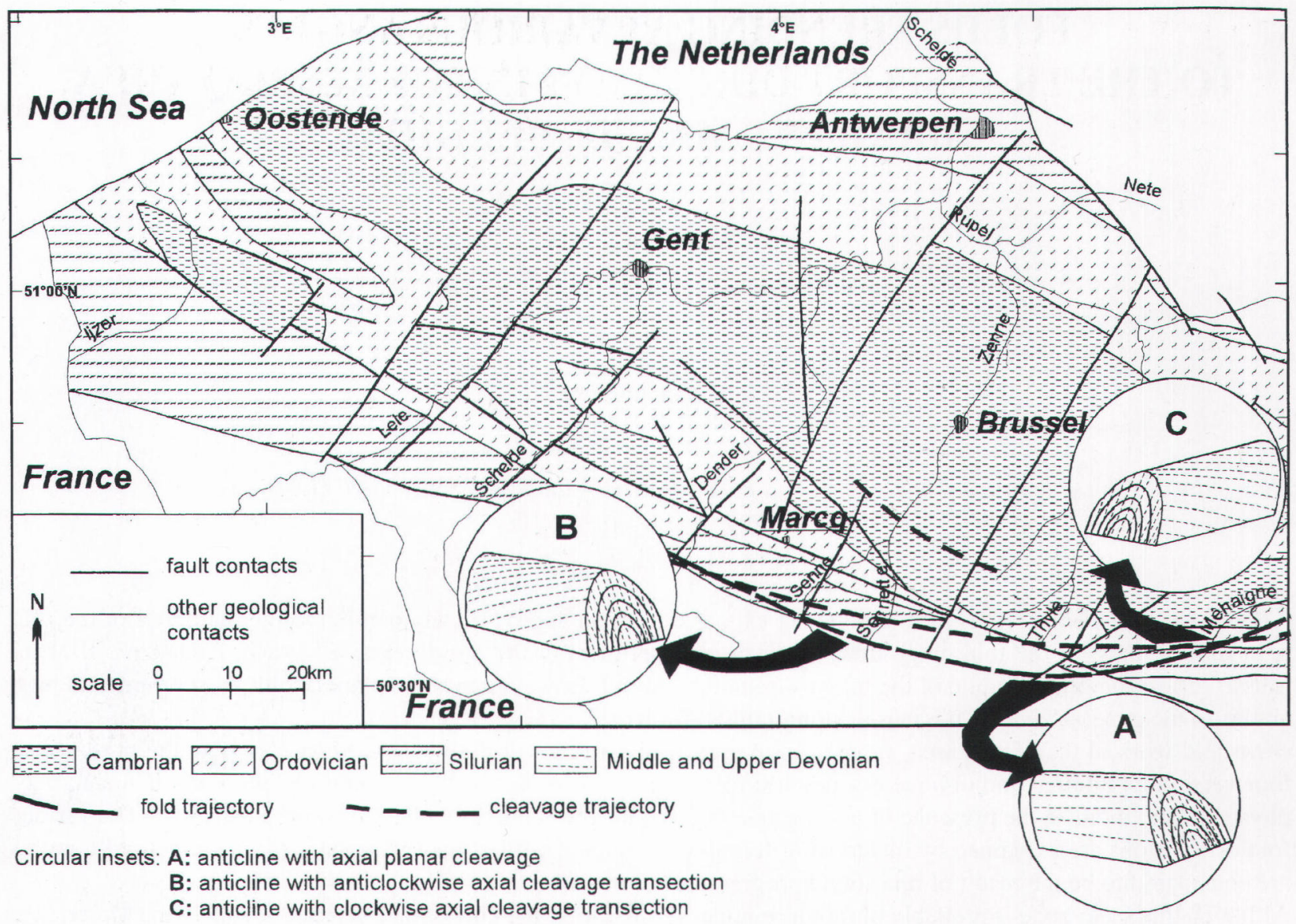

Figure 1. Geological subcrop map of the Brabant Massif (De Vos et al., 1993). The added cleavage and fold trajectories in the outcrop areas along the southern part of the massif are taken from Sintubin (1997). The circular insets schematically show the fold orientation and sense of cleavage transection in the western (B), central (A) and eastern (C) parts of the southern Brabant Massif.

This paper offers a possible solution, based on new field observations, combined with borehole and geophysical data, from the poorly exposed Marcq area, situated in the SW-part of the Brabant Massif, some $30 \mathrm{~km}$ to the SW of Brussels.

\section{Data}

\subsection{Outcrop data}

Several small discontinuous outcrops are present along the Marcq river and near its confluence with two E-Wrunning brooks (for location see figs. 2 and 3). The data include lithological observations, the geometry of structural features such as fold hinge lines, cleavage, cleavage/bedding intersections and mineral stretching lineations and the presence of alteration. These observations are summarised in table 1 . The orientation of linear features (fold hinge lines, stretching lineations) is written as plunge/plunge direction (e.g. 25/030) and the orientation of planar features as strike/dip with an indication of dip direction (e.g. 307/47 NE).
Outcrop 1. The largest and best preserved outcrop of the Marcq area is an abandoned quarry east of the Marcq river. The sediments are fine-grained distal turbidite deposits with intercalated dm-thick quartzitic convolute beds. A characteristic sedimentological feature of these deposits is the discontinuous, often lensoid-shaped nature of thin, intercalated, pale-coloured silt- to sandstone beds. The deposits belong to the Chevlipont Formation and were dated biostratigraphically (dendroid graptolites and acritarchs) as lower Tremadoc (lowermost Ordovician) (Longueville, 1997 and M. Vanguestaine, pers. comm. 1997). By analogy with Longueville (ibid), we will refer to this unit as lithostratigraphic unit 1 (L.S.U. 1). The outcrop shows an asymmetric, moderately inclined, gently NE-plunging, NW-facing syncline. Across the fold the cleavage describes a divergent cleavage fan. Both the orientations of the cleavage and the cleavage/bedding intersections indicate a small anticlockwise axial cleavage transection (sensu Johnson, 1991, see also Johnson \& Woodcock, 1991). For an understanding of the term cleavage transection we refer the reader to the insets of figure 1 . Thin sections show a rough bed- 


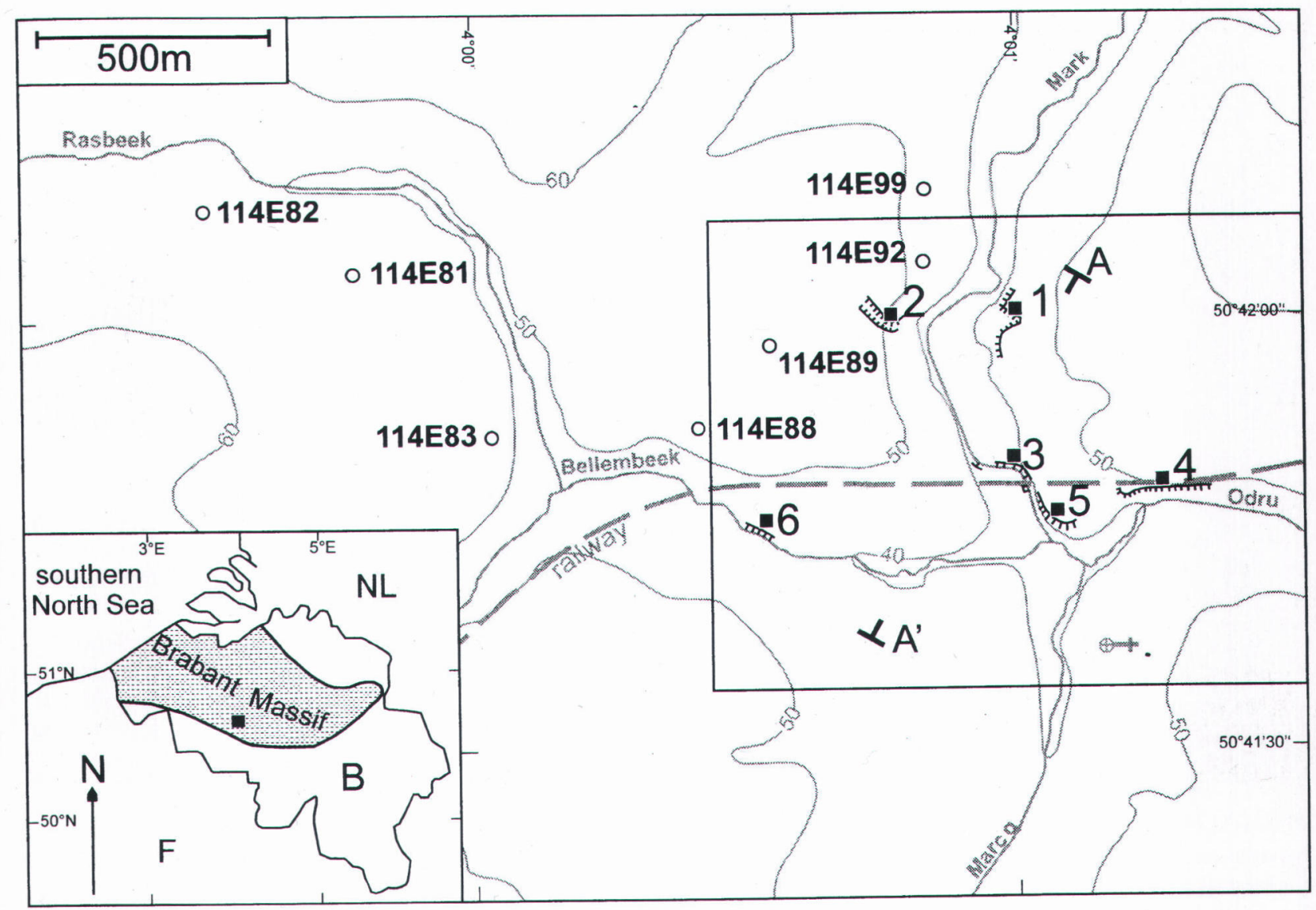

Figure 2. Topographic map of the Marcq area with the location of boreholes (114EXX) and outcrops ( $\underline{1}$ to $\underline{6})$. The frame in the eastern part of the map represents the studied outcrop area covered by fig. 3 . The black square inside the inset shows the position of the Marcq area inside the Brabant Massif (cf. fig. 1). A-A' represents the position of the schematic section of fig. 5.

\begin{tabular}{|c|c|c|c|c|c|c|c|c|}
\hline Outcrop number & 1 & 2 & 3 & 3' & $3^{\prime \prime}$ & 4 & 5 & 6 \\
\hline $\begin{array}{l}\text { Lithostratigraphic } \\
\text { unit }\end{array}$ & 1 & 1 & 2 & 2 & 2 & 2 & 3 & 3 \\
\hline $\begin{array}{l}\text { Fold hingeline } \\
\text { orientation }\end{array}$ & $25 / 030$ & $02 / 350$ & $\begin{array}{l}12 / 327(N W) \\
08 / 126(S E)\end{array}$ & 7 & 7 & $32 / 332$ & 7 & 7 \\
\hline Mean cleavage & $307 / 47 \mathrm{NE}$ & $305 / 38 \mathrm{NE}$ & $310 / 3$ & $\mathrm{NE}$ & & $306 / 48 \mathrm{NE}$ & $312 / 25 \mathrm{NE}$ & $304 / 57 \mathrm{NE}$ \\
\hline $\begin{array}{l}\text { Cleavage/bedding } \\
\text { intersections }\end{array}$ & $42 / 024$ & $21 / 339$ & $08 / 320$ & $\begin{array}{l}341 \\
013\end{array}$ & $\begin{array}{l}15 / \\
005\end{array}$ & $46 / 055$ & $13 / 355$ & $52 / 353$ \\
\hline $\begin{array}{l}\text { Sense of cleavage } \\
\text { transection }\end{array}$ & C.C.W. & C.C.W. & $\begin{array}{l}\text { C.C.W. }(N W) \\
\text { C.W. }(S E)\end{array}$ & & & C.C.W. & C.W. (?) & C.C.W. (?) \\
\hline Stretching lineations & 7 & 7 & $27 /$ & & & $\begin{array}{c}* \\
38 / 027 \\
\end{array}$ & $\begin{array}{c}* * \\
19 / 034\end{array}$ & 7 \\
\hline Sericitisation & 7 & 7 & ** & *** & $* * *$ & I & $*$ & 7 \\
\hline
\end{tabular}

Table 1. Summary of the field observations. I: not observed, C.W. and C.C.W.: respectively clockwise and counterclockwise cleavage transection, (?) uncertain since sense of transection was deduced from the difference in strike between cleavage and bedding, *: poor, **: moderate, ***: strong. In outcrop 3 two parts are distinguished: $(N W)$ and $(S E)$, respectively the NW-part and the SE-part of the outcrop. 


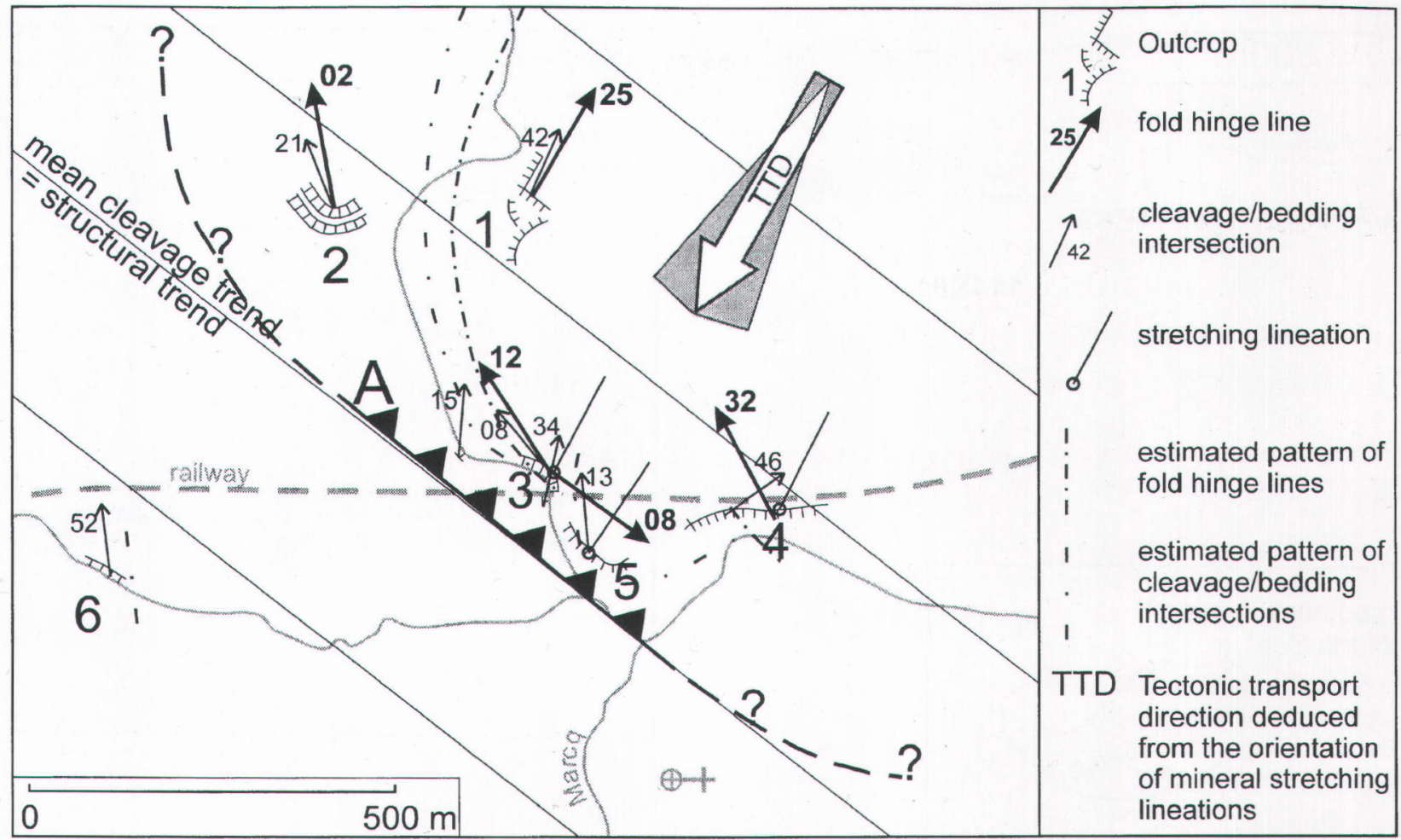

Figure 3. Simplified topographic map showing the six outcrops ( $\underline{1}$ to $\underline{6}$ ) with the orientations of the fold hinge lines, the cleavage/ bedding intersections and the stretching lineations. Also shown are the mean trend of the NE-dipping cleavage, the probable position of the low-angle reverse shear zone A (see 3.2) and the deduced patterns of the fold hinge lines and cleavage/bedding intersections. Note the two apparent arc shapes, concave to the NE, with an apparent structural break between outcrops 3 and 5 .

ding-parallel alignment of phyllosilicates (chlorite and muscovite/sericite). There is no clear alignment of these minerals along the cleavage planes.

Outcrop 2. This poorly preserved, discontinuous outcrop, situated in a road trench $300 \mathrm{~m}$ west of outcrop 1, shows the same sediments as outcrop 1 (L.S.U. 1, Chevlipont Formation). One small, asymmetric, open, subhorizontal, W-facing anticline can be observed. The distribution of the W- and E-dipping beds probably indicates the presence of several more small W-facing folds. The cleavage/bedding intersections trend anticlockwise of the fold hinge line, indicating an anticlockwise cleavage transection.

Outcrop 3. The main part of this outcrop is situated along the NE-side of the Marcq river, some $400 \mathrm{~m}$ south of outcrop 1 , just north of the railway. The deposits are light-coloured meta-rhyolites (Denaeyer \& Mortelmans, 1954, L.S.U. 2 sensu Longueville, ibid.), also described by Corin (1965) as silicified porphyry. The exact stratigraphic position of this unit is unknown. A subhorizontal, gently dipping, SW-facing anticline is oriented subparallel to the river. The cleavage forms a well-developed convergent cleavage fan around the fold (fig. 4). The anticline is non-cylindrical: the part of the fold hinge line in the SE-part of the outcrop plunges towards the SE, whereas the part of the fold hinge line in the NW-part of the outcrop plunges towards the NW. This results in a small anticlockwise cleavage transection in the NW-part of the outcrop and a small clockwise cleavage transection in the SE-part. Several bedding-parallel, dm-thick quartz veins, rich in sulphides, are present in the fold hinge zone (fig. 4). Close to the railway bridge, steeply NW-plunging microfolds on these quartz surfaces are the result of flexural slip at a small angle to the fold hinge line. Sigma-structures in thin sections from these quartz veins indicate a sinistral sense of shear. Along the outcrop the lithology gradually changes: towards the west (higher in stratigraphy) the sediments become slightly more fine-grained, with a more lustry, altered appearance and a more pervasive cleavage. Microscopic observations show a pronounced alignment of muscovite/ sericite along the cleavage planes and, in contrast to outcrop 1, an absence of chlorite. These microscopic features probably indicate that the lustry, altered appearance is the result of sericitisation. Another difference with the previous outcrops is the presence of mineral stretching lineations. These lineations are oriented subparallel to the dip direction of the cleavage (fig. 3, fig.4). Together with the lustry appearance, both the cleavage intensity and the intensity of the mineral stretching lineations increase towards the west. 


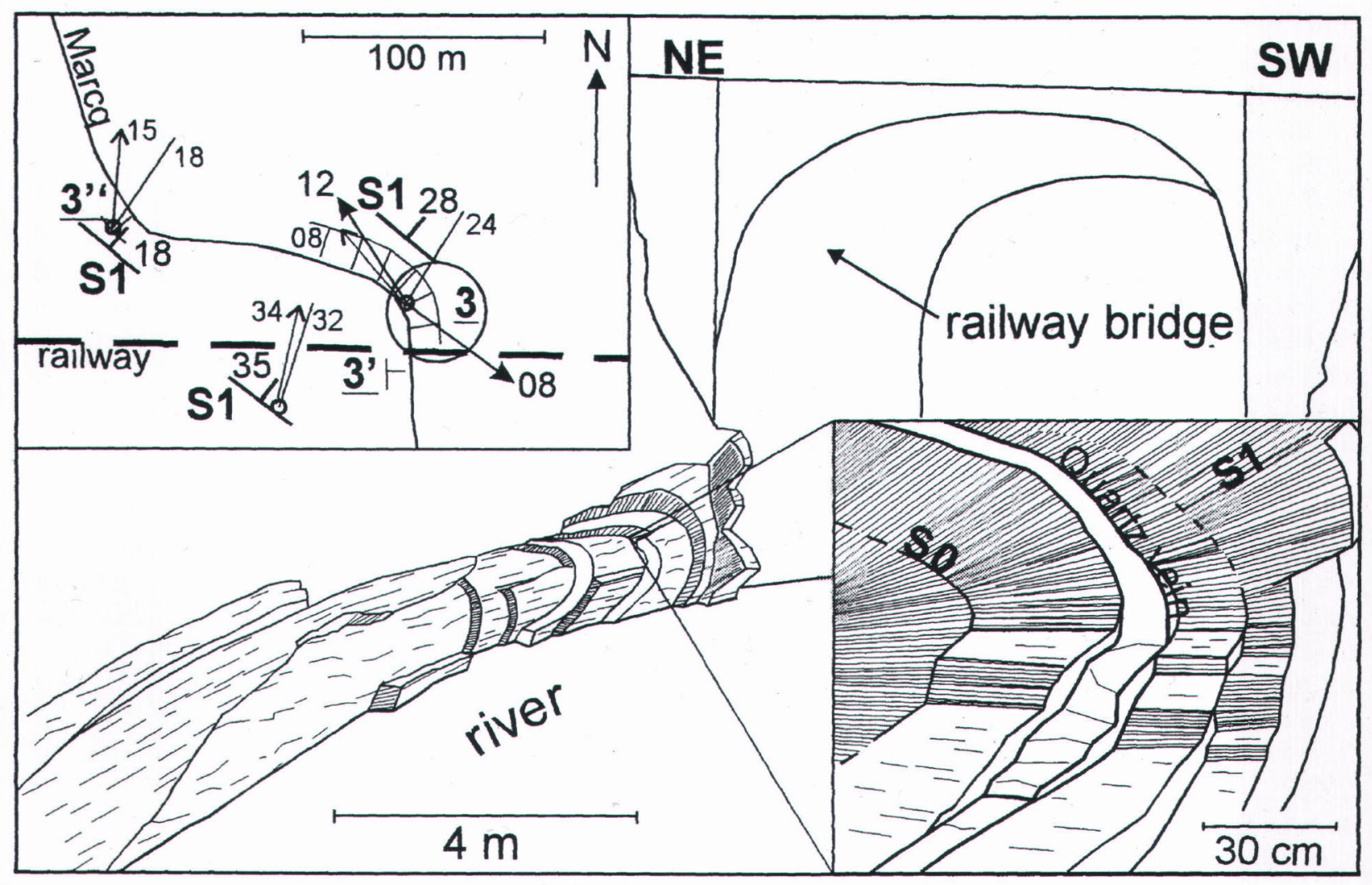

Figure 4. Outcrop 3, showing a subhorizontal, gently dipping, SW-facing, non-cylindrical antiform, running parallel to the Marcq river. The upper left inset shows the location of the sketched part of outcrop 3 (encircled), the positions of the small outcrops 3 ' and 3" and the orientations of the structural elements in each of the three outcrops. Symbols used are the same as on fig. 3. The blow-up in the lower right inset shows convergent cleavage fanning and a bedding-parallel quartz vein. S0: bedding, S1: cleavage.

Just south of the railway bridge, along the W-side of the Marcq river, a small outcrop of L.S.U. 2 is present (outcrop 3'). Sedimentological features indicate a volcano-sedimentary origin (Longueville, ibid.). Although lithologically similar to the W-part of the main outcrop, the sericitisation is less pronounced. Again mineral stretching lineations are present, subparallel to the dip direction of the cleavage. The cleavage/bedding intersections have a different orientation compared to those in the main outcrop (fig. 4).

North of the railway, in the river bend west of the main outcrop, another very small outcrop of L.S.U. 2 is present (outcrop 3", fig. 4) (cf. Longueville, ibid.). The deposits have a strongly altered, talc-like appearance. The strike of the pervasive cleavage and the plunge direction of the mineral stretching lineations are the same as in the main outcrop, but the cleavage dips less steeply and the cleavage/bedding intersections have a different orientation (fig. 4).

From the sedimentological and structural observations it is inferred that the facies of the main outcrop (3) is overlain by the finer grained facies present in the two small outcrops (3' and 3'). Since there appears to be a gradual change between them, both facies are grouped into one lithostratigraphic unit (L.S.U. 2, Longueville, ibid.) of which the exact stratigraphic position remains unknown.

Outcrop 4. This outcrop is situated some $200 \mathrm{~m}$ east of outcrop 3, along the S-side of the railway. The rocks are meta-rhyolites similar to those in outcrop 3 (L.S.U. 2), but lack the lustry, altered appearance. De la ValléePoussin \& Renard (1876, p. 145) mention a gradual transition between these volcanic rocks (outcrops 3 and 4) and the surrounding sediments (outcrop 5), an observation which points to an interstratified nature of the meta-rhyolites. Due to the weathered nature of the outcrop and the homogeneity of the deposits, the bedding is very difficult to distinguish. A small, SW-facing, moderately NW-plunging fold pattern can be observed, with the cleavage approximately axial planar to it. Unfortunately, the further continuation of the beds is not clear. In places, weakly developed stretching lineations can be observed, subparallel to the dip direction of the cleavage (fig. 3). Some $50 \mathrm{~m}$ to the west local intercalations of coarser material show a moderately E-dipping bedding. There, the cleavage/bedding intersections plunge towards the NE. 
Outcrop 5 is situated 50 to $100 \mathrm{~m}$ south of the railway along the E-side of the Marcq river. The lithology consists of dark grey to black mudstones with thin intercalated, pale-coloured, silty, parallel and cross-bedded bands. The sediments are interpreted as distal turbidite deposits. Although organic material is present, no Chitinozoa were found in the collected samples (Verniers, unpub. data). The presence of pale individual silt and sand grains in a finer grained matrix (not observed in outcrops 1 and 2), led Longueville (ibid.) to consider these sediments as belonging to a distinct lithostratigraphic unit (L.S.U. 3). However, the often discontinuous, lensoid-shaped nature of the intercalated pale-coloured beds resembles L.S.U. 1 (Chevlipont Formation). Along the outcrop the beds dip gently towards the $\mathrm{N}$ and the cleavage dips gently towards the NE. The cleavage/bedding intersections plunge gently towards the north. In the southern part of the outcrop mineral stretching lineations are present subparallel to the dip direction of the cleavage (fig. 3). There, the lustry appearance of the cleavage planes probably indicates a certain amount of sericitisation.

Outcrop 6 is situated in the riverbed of the Bellembeek, some $700 \mathrm{~m}$ west of outcrop 5. The sediments are dark grey to black mudstones with intercalated silty to sandy beds and are considered to belong to the same lithostratigraphic unit as the sediments in outcrop 5 (L.S.U. 3). Apart from other organic microfossils no Chitinozoa were found in the collected samples (Verniers, ibid.). The bedding is subvertical and the cleavage dips moderately towards the NE. The cleavage/ bedding intersections plunge moderately towards the $\mathrm{N}$ (fig. 3). No stretching lineations can be observed and there are no indications of sericitisation.

\subsection{Borehole information}

Borehole 114E92 (350 m deep, fig. 2) was drilled 200 $m$ to the NW of outcrop 1. The core description was performed by De Vos (unpub. data). The core mainly consists of rocks resembling L.S.U. 1. As in outcrops 1 and 2 (L.S.U. 1), apart from other undeterminable microfossils, no Chitinozoa were found (Verniers, unpub. data). Intercalated magmatic rocks, resembling L.S.U. 2, are present between 241 and $252 \mathrm{~m}$ depth. It is not clear whether these have a volcanic or plutonic origin (Piessens et al., 1998, cf. Corin, 1965, p. 122).

Throughout the core the rocks are strongly folded. Shear folds predominantly occur in the upper half of the core (above $170 \mathrm{~m}$ ). Although faults, fractures and mineralisations are present throughout the core, most of the fractures and faults occur in a strongly deformed and altered zone between 130 and $180 \mathrm{~m}$ depth. Faults and mineralised quartz veins are generally oriented parallel to the cleavage. Lineations and striations indicate a dip-slip movement along the cleavage planes (Piessens et al., ibid.). Sigma-structures around pyrite crystals from this highly deformed zone indicate a topto-the-SW, reverse, sense of shear (Piessens, unpub. data). An analysis of the core description shows that the dip of the cleavage gradually changes along the core. The lowest cleavage dips (between 20 and $30^{\circ}$ ) occur between a depth of 140 to $200 \mathrm{~m}$. At higher and lower levels the cleavage generally dips between 25 and $40^{\circ}$ (between 90 and $140 \mathrm{~m}$, between 200 and 250 $\mathrm{m}$ and below $310 \mathrm{~m}$ ) and between 30 and $50^{\circ}$ (above $90 \mathrm{~m}$ and between 250 and $310 \mathrm{~m}$ ). The mineralogy changes from chlorite in the shallow parts, over sericitechlorite, to a dominantly sericite composition from 140 $\mathrm{m}$ onwards. The zone with the strongest sericitisation is situated between 150 and $180 \mathrm{~m}$ depth. Below 200 $\mathrm{m}$, the mineralogy changes again to dominantly chlorite. This sericitisation is thought to be of syntectonic hydrothermal origin (Piessens et al., ibid.).

X-ray pole figure goniometry was performed on a sericitised sample from a depth of $180,65 \mathrm{~m}$. The mica (001) pole figure pattern shows an orthorhombic symmetry, centred around the cleavage pole with a high degree of preferred orientation. Similar to the mineral stretching lineations, this distribution indicates differential stretching in the cleavage plane (Sintubin, unpub. data).

\section{Kinematic model}

\subsection{Synthesis of structural data}

The cleavage/fold relationships in the Marcq area favour one single progressive deformation. Where they can be observed, mineral stretching lineations are oriented subparallel to the dip direction of the cleavage (mean lineation orientation: $27 / 030$ ). Since these lineations are considered to parallel the extension direction (X-direction of the finite strain ellipsoid) (Ramsay \& Huber, 1987, Price \& Cosgrove, 1990) and there are no indications of transpressive movements, the local tectonic transport direction in the Marcq area is considered to be oriented NE-SW $\left(030^{\circ}-210^{\circ}\right)$, approximately at right angles to the strike of the cleavage. As can be seen on figure 5, the fold asymmetry and the cleavage dip both indicate a SW-verging tectonic transport.

The simplified map on figure 3 shows the orientations of the fold hinge lines and the mean cleavage/bedding intersections for each outcrop. In contrast to the constant strike of the cleavage, the orientation of the fold hinge lines and cleavage/bedding intersections is highly variable. Only in outcrops 3 and 4, the folds are perpendicular to the transport direction (transverse folds, sensu Mies, 1993). In outcrop 1 the fold trends ap- 


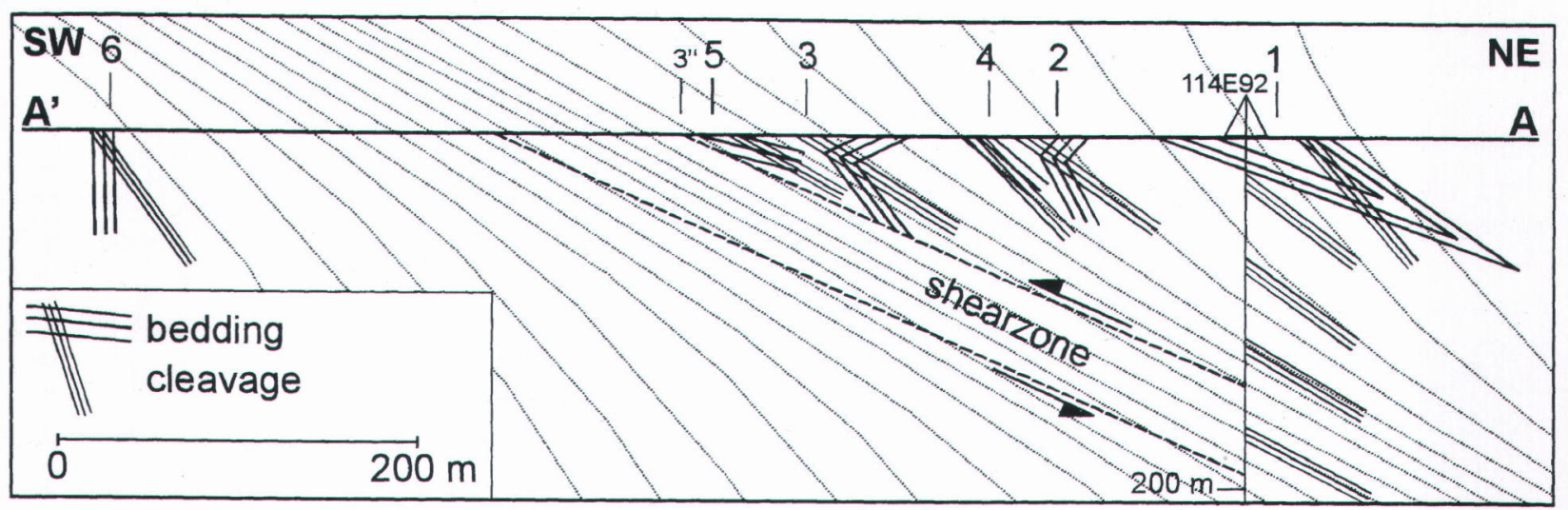

Figure 5. Schematic section across the Marcq area parallel to the transport direction $\left(030^{\circ}-210^{\circ}\right)$, showing bedding, cleavage and deduced cleavage-dip trajectories. Numbers 1 to 6 refer to outcrops. The upper part of borehole 114E92 is shown (total depth: $350 \mathrm{~m}$ ), intersecting the centre of the shear zone at a depth between 140 and $190 \mathrm{~m}$. The position of the section line (A-A') is shown on fig. 2.

proximately parallel to the transport direction (longitudinal fold, sensu Mies, ibid.). However, as shown on the stereographic projection (fig. 6), the fold hinge lines (best fit girdle: 310/28 NE) and the cleavage/bedding intersections (best fit girdle: $315 / 44 \mathrm{NE}$ ) approximately lie in the mean cleavage plane (308/43 NE), which approximates the XY-plane of the bulk finite strain ellipsoid.

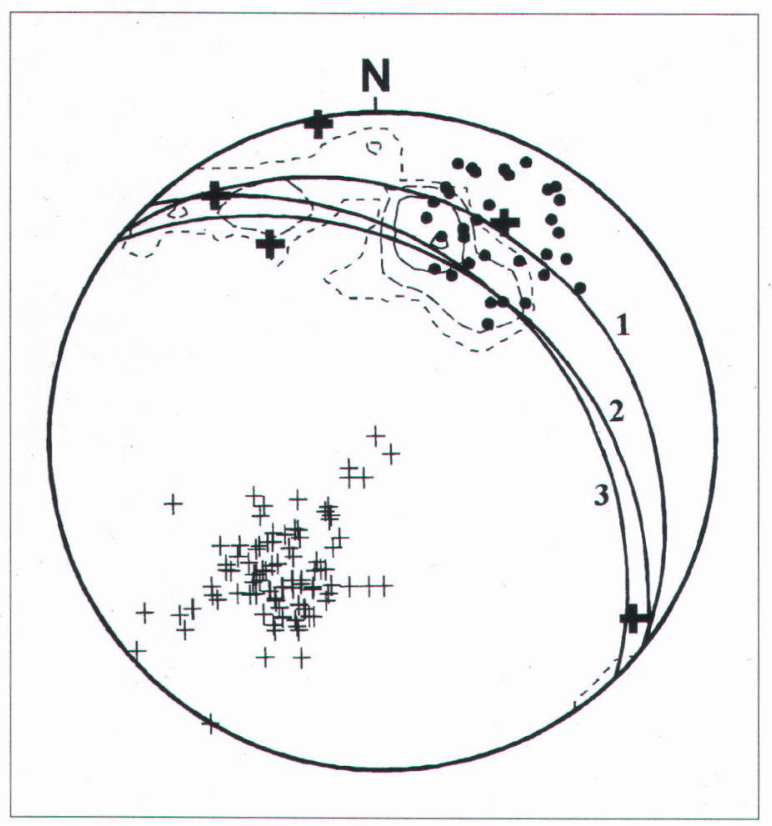

Figure 6. Lower hemisphere equal-area stereographic projection showing the fold hinge lines (thick black crosses), the poles to cleavage (+), the cleavage/bedding intersections (contours), the stretching lineations (filled circles), the best fit girdle through the fold hinge lines (310/28 NE, girdle 1), the mean cleavage plane (308/43 NE, girdle 2$)$ and the best fit girdle through the cleavage/bedding intersections (315/ $44 \mathrm{NE}$, girdle 3).
Along section (fig. 5) the cleavage dip gradually changes, apparently describing a sigmoidal pattern, with the lowest cleavage dips situated near outcrop 3 ". A similar gradual change is found along the length of core 114E92. There, the lowest cleavage dips occur between a depth of 140 to $200 \mathrm{~m}$.

Mineral stretching lineations are only observed in outcrops 3, 4 and 5 and are most pronounced in outcrops 3 and 5 (table 1). These two outcrops also show the most pervasive cleavage, the lowest cleavage dips and a considerable to high degree of sericitisation. On the other hand, hand specimens from outcrops with moderate cleavage dips (outcrops 1, 2 and 6) show no signs of sericitisation or mineral stretching lineations. As such, there seems to be a relationship between the degree of sericitisation, the presence of mineral stretching lineations, the cleavage dip and the cleavage intensity. One might argue that this relationship is lithology-controlled (e.g. finer grained rocks have a more pervasive cleavage than coarser grained rocks). Considering the fact that outcrops 3 and 4 , on the one hand (L.S.U. 2), and outcrops 5 and 6, on the other hand (L.S.U. 3), belong to the same lithostratigraphic units, but differ on the basis of alteration and deformation, we can argue that lithology cannot be of much importance here. We interpret the observed relationship as predominantly structurally controlled. A similar relationship is found in core 114E92. There, the zone of strong sericitisation coincides with the most deformed zone and the zone with the lowest cleavage dips.

\subsection{Structural interpretation}

The observations indicate the presence of a high-strain zone. The more pervasive cleavage and the presence of stretching lineations in outcrops 3 and 5, as compared to the less pervasive cleavage and the absence 
of stretching lineations in outcrops 1,2 and 6, and the difference in cleavage attitude between outcrops 1 and 3 , is compatible with a zone of localised high deformation. The central part of this high-strain zone is the strongly altered and deformed zone encountered in borehole 114E92 between 140 and 190 m depth.

This high-strain zone can be interpreted as a low-angle reverse shear zone with a top-to-the-SW displacement. Microscopically, sigma-structures in the strongly altered high-strain zone in core 114E92 show a univergent, top-to-the-SW, asymmetry. Macroscopically, apart from the fold asymmetry, also the sigmoidal change in cleavage dip in the Marcq area points to a top-to-the-SW displacement along this high-strain zone (fig. 5). As shown by Ramsay \& Graham (1970) the central parts (high strains) of ductile shear zones are characterised by a pervasive cleavage oriented at a small angle to the shear zone walls (outcrops 3 and 5), whereas the margins (less strained) show a moderate angle between the cleavage and the shear zone walls (outcrops 1, 2, 4 and 6). This results in a sigmoidal pattern of the cleavage (Ramsay \& Graham, 1970, Ramsay \& Huber, 1987).

The orientation of this shear zone and the probable position of the trace of the shear zone can be deduced from outcrop and borehole data. Since the lowest cleavage dip in the outcrop area is about $25^{\circ} \mathrm{NE}$ and the transport direction (X-axis of the finite strain ellipsoid) is approximately at right angles to the strike of the cleavage, we tentatively argue that the orientation of the shear plane is $\pm 308 / 25 \mathrm{NE}$ (XY-plane of the finite strain ellipsoid within the shear zone). Based on field observations this shear zone is expected to reach the surface somewhere to the SW of, but close to, outcrop 3" (westernmost part of outcrop 3). In borehole $114 \mathrm{E} 92$, in the strongly altered and deformed zone between 140 and $190 \mathrm{~m}$ depth, the parallelism between the faults and the cleavage seems to confirm the deduced shear zone orientation. Trigonometry, using the deduced orientation of the shear zone and the depth of the most deformed and altered zone in the core (between 140 and $190 \mathrm{~m}$ ), indeed shows that the centre of the shear zone should reach the surface some $50 \mathrm{~m}$ to the southwest of outcrop 3" (fig. 5 and A on fig. 3 and 11).

The close match between the best-fit girdle through the fold hinge lines (310/28 NE, fig. 6) and the deduced orientation of the shear zone may indicate that the orientation of the fold hinge lines is a result of the shearing process

\subsection{A structural model to explain the vari- ous fold orientations}

On figure 3 both the fold hinge line and cleavage/bedding intersection trajectories show two arcuate patterns concave to the NE. As shown on figure 6, both types of lineations approximately lie in the XY-plane of the finite strain ellipsoid. Geometrically, this is compatible with sheath folding (Park, 1988), and, as known from experiments (e.g. Cobbold \& Quinquis, 1980, Marques \& Cobbold, 1995) and from field observations (e.g. Fossen \& Rykkelid, 1990), shear zones favour the formation of sheath folds. However, sheath folds have not been observed in the Marcq area. Furthermore, the degree of deformation and metamorphism (epizone-lower anchizone, Geerkens, 1992) in the outcrops outside the high-strain zone is rather low as compared to those in natural sheath fold environments. It follows that, although the presence of sheath folds in the Marcq area cannot be ruled out completely, sheath folding, or any model using primarily passive fold hinge line rotation to explain the various orientations of the fold hinge lines, especially the orientation of the syncline in outcrop 1 , should be rejected.

Coward \& Potts (1983) examined the strain patterns at the tips of shear and thrust zones. Intense strains develop at the tips where the thrust sticks. The resulting layer-parallel shortening may cause the rocks to fold, producing asymmetric folds. This happens both at frontal and lateral tips. At the frontal tips the rocks are deformed by progressive simple shear $\mathrm{g}_{1}$. This simple shear $\mathrm{g}_{1}$, with a movement direction $\mathrm{X}$, acts on the plane normal to Y (fig. 7). At lateral tips there is an additional simple shear $\mathrm{g}_{2}$, acting on the plane normal to $\mathrm{Z}$, but with the same movement direction. Combinations of both shear strains give rise to a simple shear $\mathrm{g}_{\mathrm{s}}$, with a shear plane oblique to that of $g_{1}$ and $g_{2}$, but with the

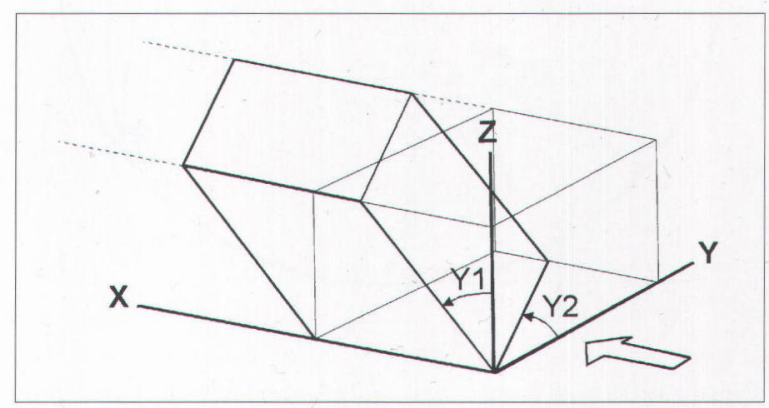

Figure 7. The shear strain $g_{1}=\tan Y 1$, related to the main layer parallel shear in a thrust system and the shear strain $g_{2}$ $=\tan \mathrm{Y} 2$ due to differential movement of this thrust in a lateral tip, shown relative to the co-ordinate system X, Y and $\mathrm{Z}$. The transport direction is indicated by the arrow (Coward \& Potts, 1983). 


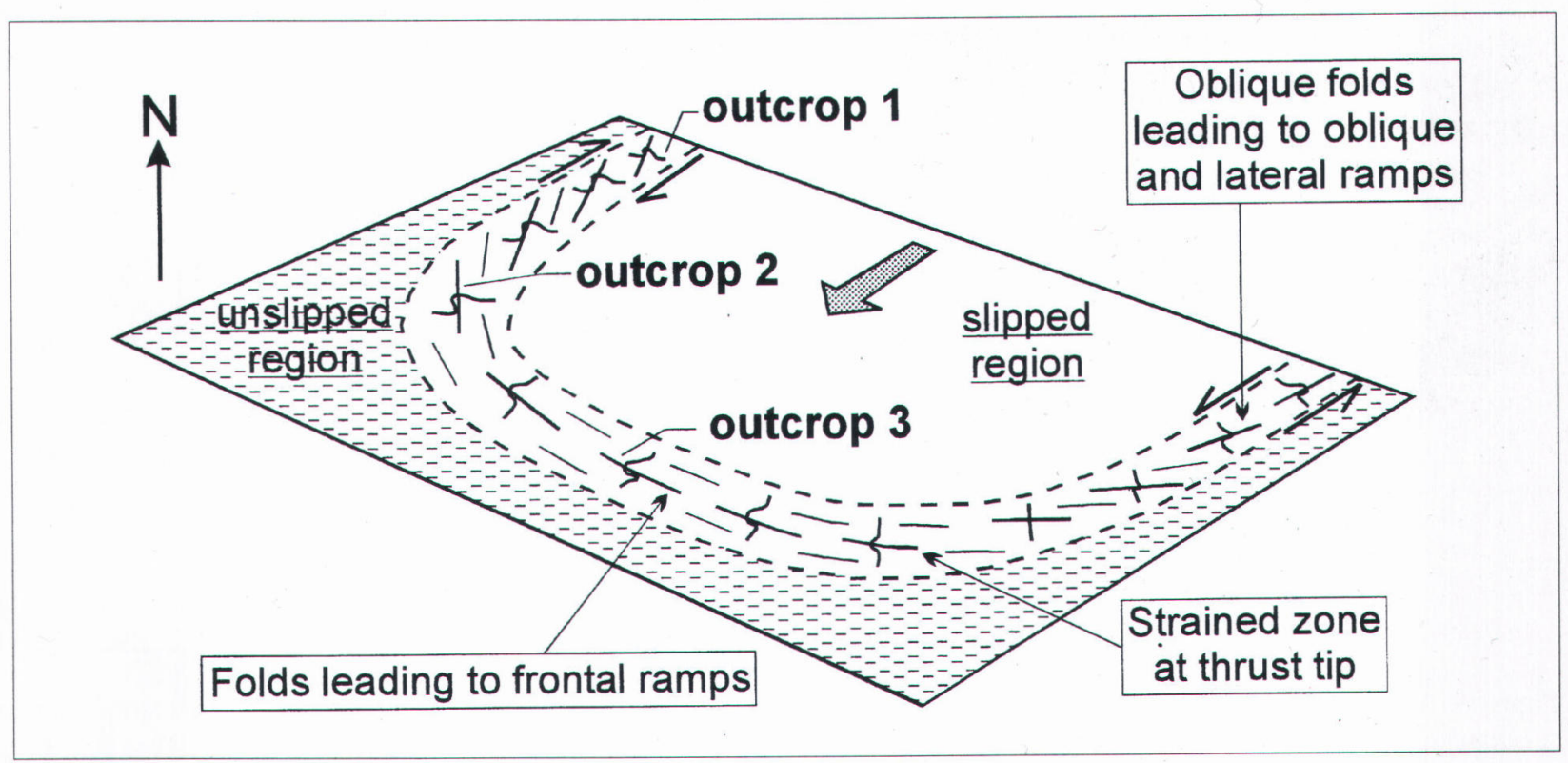

Figure 8. A thrust plane showing the strained tip region between the slipped and unslipped regions (after Coward \& Potts, 1983). Outcrops 1 to 3 are fitted into the model (cf. fig. 3).

same movement direction. This differential movement leads to the production of folds oblique to the transport direction. With an increase in strain intensity the fold hinge lines will rotate towards the transport direction, but will differ from normal sheath folds in that the hinge lines should not be curvilinear and the folds should all face one way (Coward \& Potts, 1983).

This model is compatible with the structural observations in the Marcq area (fig. 8, cf. fig. 3). It explains the various orientations of the fold hinge lines and cleavage/bedding intersections without necessitating the high strains necessary for sheath fold development or passive fold hinge line rotation. The longitudinal folds formed at a lateral tip $\left(g_{1}<g_{2}\right.$; e.g. outcrop 1) and the transverse folds formed at a frontal tip $\left(\mathrm{g}_{1}>\right.$ $g_{2}$; e.g. outcrop 3 ). The folds trending at moderate angles to the transport direction (e.g. outcrop 2) formed at an oblique tip. At the frontal tip the folds face towards the SW and at the lateral tip the folds face towards the NW. The study area is dominated by an anticlockwise cleavage transection. This may be in agreement with the model, considering that most of the area seems to be occupied by an oblique to lateral tip, characterised by a dextral shear. At the frontal tip (the central part of outcrop 3) the cleavage transection can be ignored. In the SE-part of outcrop 3, a small clockwise cleavage transection is present. Also this seems to match the model. This part of the outcrop has a hinge line at a high angle but oblique to the transport direction and is probably situated at the transition between a frontal and an oblique tip, characterised by a small amount of sinistral shear. This would explain the steeply plunging microfolds and the sinistral shear along the bedding-parallel quartz veins. The apparent clockwise cleavage transection in outcrop 5 cannot readily be explained. Possibly this is related to the apparent structural break between the two arcs (between outcrops 3 and 5).

\section{Discussion}

In contrast to the various orientations of the fold hinge lines and cleavage/bedding intersections, the strike of the cleavage remains constant across the outcrop area. Where observed, mineral stretching lineations indicate a tectonic transport (X-direction) at right angles to the strike of the cleavage (XY-plane of the finite strain ellipsoid). The structural data are explained by means of differential movement within a low-angle reverse shear zone (Coward \& Potts, 1983). The longitudinal folds formed at a lateral tip (e.g. outcrop 1) and the transverse folds formed at a frontal tip (e.g. outcrop 3 ).

To reduce the problem of the low degree of exposure in the Marcq area, geophysical data were used besides borehole data to check the presented model.

\subsection{Comparison with aeromagnetic and AFMAG data}

On the aeromagnetic map of Chacksfield et al. (1993) a strong WNW-ESE-trending $\left(290^{\circ}-110^{\circ}\right)$ aeromagnetic lineament is present (fig. 9), apparently running through the Marcq area. This represents the trace of the so-called Nieuwpoort-Asquempont fault zone (De Vos et al., 


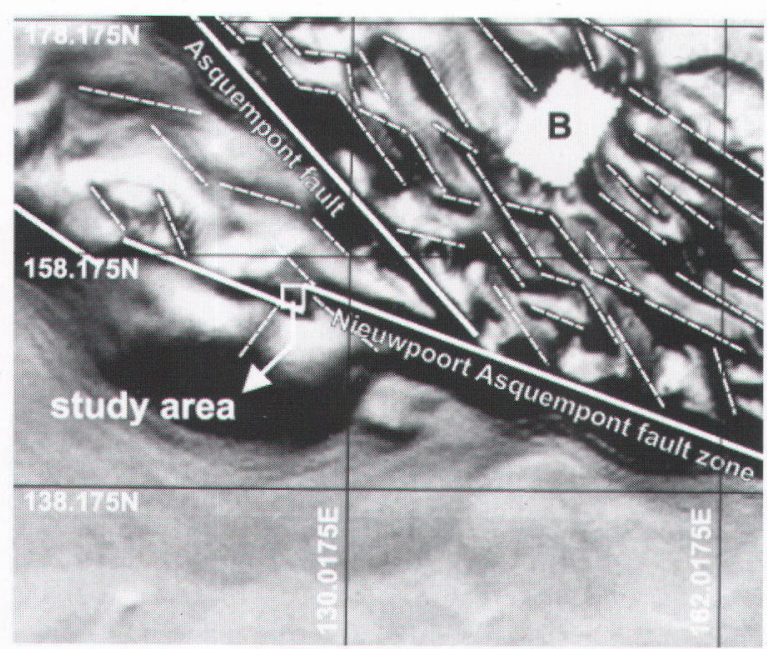

Figure 9. Aeromagnetic image, reduced to the pole, of the southwestern and central part of the Brabant Massif illuminated from the north (Chacksfield et al., 1993). The most apparent aeromagnetic lineaments are traced (white lines). The small white square shows the area of fig. 3 . Belgian Lambert coordinates are shown in kilometers.

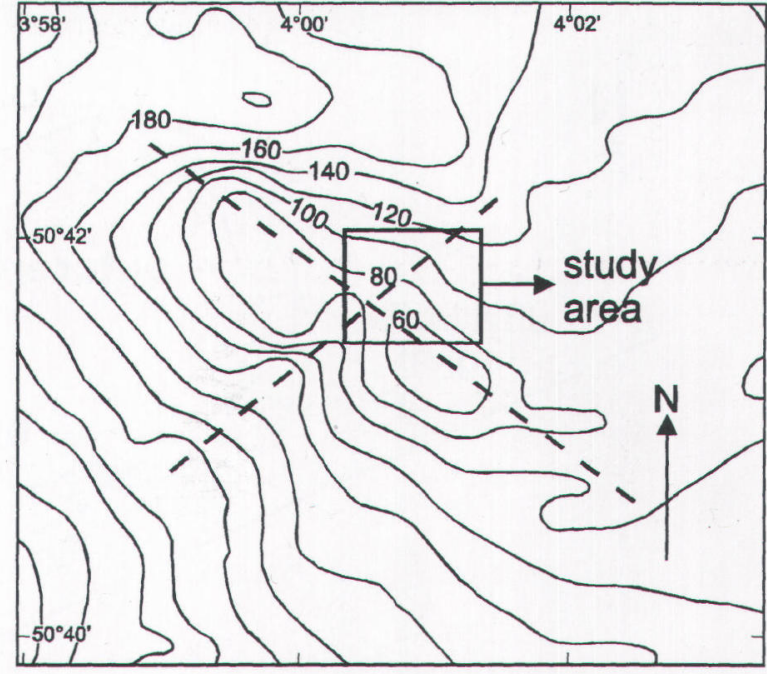

Figure 10. Simplified image of part of the aeromagnetic map of the Belgian Geological Survey (1994), reduced to the pole. Contour lines are given in $\mathrm{nT}$. The small square represents the area of fig. 3 . Two trends are visible across the Marcq area: a NW-SE-trend (central axis of the aeromagnetic trough) and a NE-SW-trend (at right angles to the former).

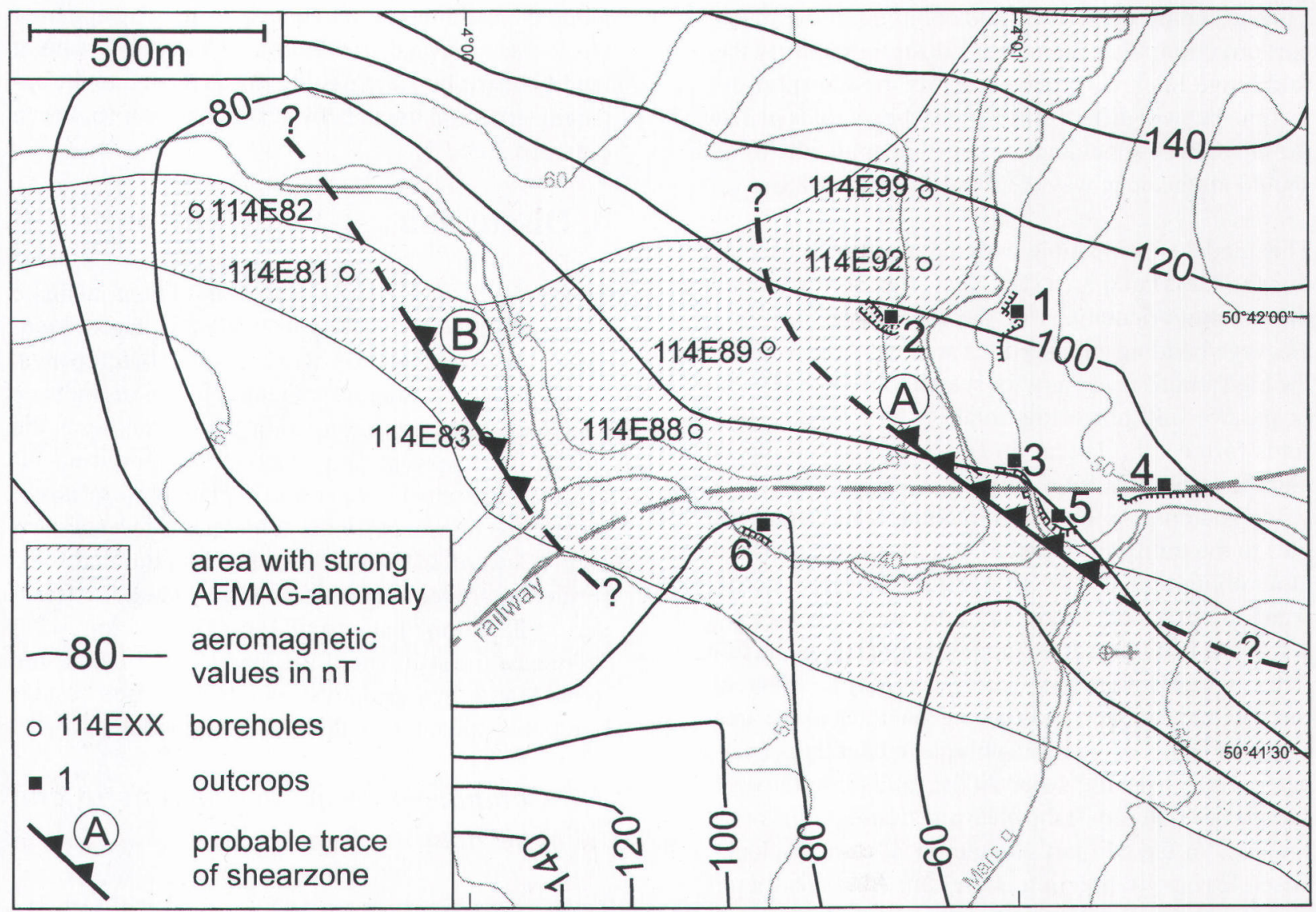

Figure 11. Topographic map of fig. 2, showing the positions of the boreholes, the T-shaped AFMAG anomaly pattern (Sterpin \& de Vos, 1996, Sterpin, pers. comm. 1998), the aeromagnetic contour lines (B.G.S., 1994, cf. fig. 10) and the probable positions of the traces of shear zones A and B. It is important to note that the exact position and orientation of shear zone B is not known. The same accounts for the lateral prolongation of both shear zone traces A and B (? and dashed lines). 
1993). Middle Devonian strike-slip movements are thought to have taken place along the OudenaardeBierghes-segment of this fault zone (André \& Deutsch, 1985). Although this WNW-ESE-trending fault zone runs through the Marcq area, our observations do not yield evidence for its existence. Its apparent orientation (WNW-ESE) is different from the structural trend (NWSE), and, as indicated by striations and stretching lineations, the transport direction in the Marcq area (NE$\mathrm{SW}$ ) is different from the supposed movement direction along this fault zone (strike-slip, i.e. WNW-ESE). A closer inspection of the aeromagnetic map reveals a close set of NW-SE-trending lineaments in the central part of the Brabant Massif. The most apparent of these lineaments represents the Asquempont fault, which places the Lower Cambrian magnetite bearing Tubize Group on top of younger deposits. Although less distinct, similar lineaments are present further to the southwest. On the more detailed aeromagnetic map of the Belgian Geological Survey (1994), these NW-SE-oriented lineaments form the dominant trend. Furthermore, this map shows the presence of a small, elongated area of less positive aeromagnetic values in the SW-part of the outcrop area (figs. 10 and 11). The long axis of this trough-like area has a NW-SE orientation $\left(310^{\circ}-130^{\circ}\right)$, parallel to the structural trend in the Marcq area, and is cut by a NE-SW-trending anomaly, running parallel to the Marcq river.

Several AFMAG studies were performed in the Brabant Massif (Sterpin \& De Vos, 1996). For background information on the AFMAG method (Audio Frequency Magnetic Field) we refer the reader to Parasnis (1975) and Griffiths \& King (1981). In the Marcq area, a NESW-trending AFMAG anomaly, running parallel to the Marcq river, apparently abuts against a NW-SEtrending one, leading to an overall T-shaped pattern (fig. 11) (Sterpin \& De Vos, 1996, Sterpin, pers. comm. 1997). The orientation of the former parallels the NESW-trending aeromagnetic anomaly (B.G.S., 1994), the latter approximately coincides with the long axis of the aeromagnetic low.

On the one hand, it appears that the orientation of the NW-SE-trending aeromagnetic and AFMAG anomalies matches the structural trend. Furthermore, the position of these anomalies (fig. 11) roughly coincides with the area where the shear zone is expected to reach the surface. However, on the other hand, the NE-SWtrending anomalies may suggest that the situation is more complex.

\subsection{Problems and possible solutions}

Reverse shear zones are expected to place older rocks on top of younger rocks. Although the structural observations in the study area indicate a reverse, top-to-
the-SW sense of shearing, a clear reverse shear displacement does not come forward from the distribution of the three lithostratigraphic units: each unit is present both in the hanging wall and the footwall of shear zone A (fig. 3, fig. 11). The trace of the centre of this shear zone is thought to be situated between outcrops 5 and 6 , both containing rocks of the same lithostratigraphic unit (L.S.U. 3). Similarly, in core 114E92, L.S.U. 1 (lower Tremadoc) is present both in the hanging wall and the footwall of this shear zone. Furthermore, the magmatic rocks of L.S.U. 2 are present both above (outcrops 3 and 4) and below (core 114E92) the centre of the shear zone. This apparent discrepancy between the structural data and the distribution of the lithostratigraphic units can be explained by arguing that only a relatively small displacement took place along this shear zone.

A reverse stratigraphic displacement does, however, seem to be present in the study area. Micropalaeontological analyses with Chitinozoa on cuttings from boreholes 114E81, 114E82 and 114E83 (fig. 11) (Van Grootel, 1995, Verniers, unpub. data) revealed an Upper Ordovician age (lower Caradoc in borehole 114E82). The resulting proximity between the Upper Ordovician (boreholes) and the lowermost Ordovician (outcrops 1 and 2), only allows for a maximum thickness of less than $900 \mathrm{~m}$ for the largest part of the Ordovician system. This is difficult to explain stratigraphically, without invoking the presence of a reverse fault or shear zone. A pronounced sericitisation, present in the upper parts of borehole 114E83, seems compatible with the presence of a second shear zone (B on figure 11). Furthermore, taking into account the volcanic origin of the magmatic rocks of L.S.U. 2 (de la Vallée Poussin \& Renard, 1876, Denaeyer \& Mortelmans, 1954), the interstratified nature of L.S.U. 2 and L.S.U. 3 (de la Vallée Poussin \& Renard, 1876), the presence of L.S.U. 2 amidst rocks resembling L.S.U. 1 (borehole 114E92), the lithological similarities between L.S.U. 1 and L.S.U. 3, and the absence of Chitinozoa (i.e. organic walled microfossils which only came into existence during the upper Tremadoc (Paris, 1996)) in samples of L.S.U. 1 and L.S.U. 3, both containing organic microfossils, it is possible that the three lithostratigraphic units all have a similar (lower) Tremadoc age. If this is the case, the proximity between the Upper Ordovician (boreholes 114E81, -82, -83) and the Tremadoc (outcrops 1 to 6) would be impossible to explain without invoking the presence of a reverse shear or fault zone in between outcrop 6 and borehole 114E83. As well the strong sericitisation in the upper parts of borehole 114E83 as the geophysical anomaly patterns (fig. 11) seem compatible with this hypothesis. Note that this (hypothetical) shear zone B (fig. 11) would have a relatively large displacement as compared to shear zone A. 
Although the NW-SE-trending AFMAG anomaly approximately coincides with the structural trend, the NESW-trending anomaly seems to imply a NE-SWtrending conductive zone, at right angles to the overall structural trend. Possibly this anomaly is an artefact. Brooks, rivers or sections of them running parallel to the geological strike, which is the case in the northern part of the outcrop area (fig. 3), may be expected to give strong anomalies (Parasnis, 1975). Also the presence of a Tertiary clay cover to the NW and SE of the river, which has at least partly been eroded inside the river valley, may obscure the AFMAG signal of a relatively deep conductor (between 140 and $190 \mathrm{~m}$ in core 114E92) (Sterpin, pers. comm. 1998). Another possibility is the presence of a lateral fault or ramp structure underneath the Marcq river (cf. Parasnis, 1975).

\subsection{Possible implications for the deforma- tion inside the Brabant Massif}

Although the Marcq area is rather small, the kinematic model presented may have some implications for a relatively large part of the Brabant Massif. Several features on the geological map (De Vos et al., 1993) indicate that the structure of the massif is more complex than what would appear from the term "fold belt". The results of the Marcq area can be used to put forward some additional ideas concerning the structure, the kinematics and the tectonic history of the southwestern part of the Brabant Massif.

The aeromagnetic maps (Chacksfield et al., 1993, B.G.S., 1994) show a close set of NW-SE-trending aeromagnetic lineaments in the central part of the Brabant Massif. Since one of these lineaments represents the trace of the reverse Asquempont fault (cf. Legrand, 1967) and also the shearing in the Marcq area is related to an aeromagnetic feature, it may be possible that also other NW-SE-trending aeromagnetic lineaments in the central part of the Brabant Massif are the reflection of reverse shear zones and/or thrusts. Gravimetric data can offer a solution to the origin of reverse shear zones and/or thrusts: besides controlling the distribution of folds and cleavage, the large lowdensity, granitic, body in the subsurface of Flanders (the presumed granitic batholith of Flanders (De Vos, 1997)), was probably partially overthrusted by the core of the Brabant Massif.

On the aeromagnetic map of Chacksfield et al. (1993) the Marcq area is situated within the large WNW-ESEtrending anomaly (fig. 9), commonly attributed to the Nieuwpoort-Asquempont fault zone (De Vos et al., 1993). However, the structural observations from the Marcq area cannot be linked to the orientation of, and the supposed Givetian lateral movements along parts of (André \& Deutsch, 1985), this fault zone.

In the Marcq area, the coincidence between the sericitisation and the reverse shear zone(s) implies that an Upper Ordovician, batholith emplacement-related origin of the hydrothermal sericite, as shown in the Lowell \& Guilbert model (Vansteelandt, 1993, p.17), can be ruled out. Instead, it points to a genetic relationship between the shear zone(s) and the hydrothermal sericite. Probably the pronounced sericitisation in the Marcq area has a syntectonic, shearing-related, origin (cf. Piessens et al., 1998).

\section{Conclusions}

The attitude of the structural elements in the Marcq area, especially the various orientations of the fold hinge lines and cleavage/bedding intersections, can be explained by differential movement within a low-angle reverse shear zone. Longitudinal folds formed at a lateral tip and transverse folds at a frontal tip. Borehole and geophysical data are compatible with the presence of, at least one, low-angle reverse shear zone.

All the structural features are thought to have formed under the influence of a single progressive deformation, which acted on the Brabant Massif from the Early to early Middle Devonian (Van Grootel et al., 1997).

Although the displacement along the reverse shear zone is probably relatively small and of local importance, the presented model has several possible implications for the kinematics and tectonic evolution of the southwestern part of the Brabant Massif: 1) a more widespread occurrence of reverse shear zones and/or thrusts; 2) a questioning of the tectonic role of the NieuwpoortAsquempont fault zone in the Marcq area and 3) a shearing-related, syntectonic, origin of the sericitisation.

\section{Acknowledgements}

J. Verniers, M. Sintubin, G. Van Grootel, M. Vanguestaine, and G. Longueville are thanked for their constructive remarks and biostratigraphical datations. The author is grateful to W. De Vos, K. Piessens and M. Sterpin for providing unpublished data. Special thanks to J. W. Cosgrove and M. P. Coward for the stimulating discussions concerning the interpretation of the structural data. T. N. Debacker is research assistant of the Fund for Scientific Research-Flanders (F.W.O.Vlaanderen). This work frames into the Research Project NR. G.0084.97 of F.W.O.-Vlaanderen. 


\section{References}

ANDRÉ, L. \& DEUTSCH, S., 1985. Very low-grade metamorphic $\mathrm{Sr}$ isotopic resettings of magmatic rocks and minerals: evidence for a late Givetian strike-slip division of the Brabant Massif, Belgium. Journal of the Geological Society, London, 142: 911-923.

BELGIAN GEOLOGICAL SURVEY, 1994. Aeromagnetic map of the Brabant Massif: residual total field reduced to the pole. Scale $1 / 100000$.

CHACKSFIELD, B., DE VOS, W., D'HOOGE, L., DUSAR, M., LEE, M., POITEVIN, C., ROYLES, C. \& VERNIERS, J., 1993. A new look at Belgian aeromagnetic and gravity data through image-based display and integrated modelling techniques. Geological Magazine, 130: 583-591.

COBBOLD, P.R. \& QUINQUIS, H., 1980. Development of sheath folds in shear regimes. Journal of Structural Geology, 2: 119-126.

CORIN, F., 1965. Atlas des roches éruptives de Belgique. Mémoires pour servir à l'explication des Cartes géologiques et minières de la Belgique, 4: 1-190.

COWARD, M.P. \& POTTS, G.J., 1983. Complex strain patterns developed at the frontal and lateral tips to shear zones and thrust zones. Journal of Structural Geology, 5: 383-399.

DE LA VALLÉE POUSSIN, CH. \& RENARD, A.F., 1876. Mémoire sur les caractères minéralogiques et stratigraphiques des roches dites plutoniennes de la Belgique et de l'Ardenne française, 264 p. F. Hayez, Bruxelles.

DENAEYER, M.E. \& MORTELMANS, G., 1954. Les roches éruptives. In: Prodrôme d'une description géologique de la Belgique: 747-792, Liège.

DE VOS, W., 1997. Influence of the granitic batholith of Flanders on Acadian and later deformation. Aardkundige Mededelingen, 8: 49-52.

DE VOS, W., VERNIERS, J., HERBOSCH, A. \& VANGUESTAINE, M., 1993. A new geological map of the Brabant Massif, Belgium. Geological Magazine, 130: 605-611.

FOSSEN, H. \& RYKKELID, E., 1990. Shear zone structures in the Oygarden area, West Norway. Tectonophysics, 174: 385-397.

FOURMARIER, P., 1914. La poussée calédonienne dans le massif siluro-cambrien du Brabant. Annales de la Société Géologique de Belgique, 41: 300-314.

FOURMARIER, P., 1921. La tectonique du Brabant et des régions voisines. Mémoires de l'Académie royale de Belgique, Classe des Sciences, 4: 1-95.

GEERKENS, B., 1992. La cristallinité de l'illite dans le bord sud du Massif de Brabant. Annales de la Société Géologique de Belgique, 115: 288-305.

GRIFFITHS, D.H. \& KING, R.F., 1981. Applied geophysics for geologists \& engineers: the elements of geophysical prospecting, 230 p., Pergamon Press, London.
JOHNSON, T.E., 1991. Nomenclature and geometric classification of cleavage-transected folds. Journal of Structural Geology, 13: 261-274.

JOHNSON, T.E. \& WOODCOCK, N.H., 1991. Detecting cleavage-transected folds using cleavage-bedding intersections. Journal of Structural Geology, 13: 919-925.

LEGRAND, R., 1967. Ronquières, documents géologiques. Mémoires pour servir à l'explication des Cartes géologiques et minières de la Belgique, 6: 160.

LONGUEVILLE, G., 1997. Geologische kartering, litho- en biostratigrafie van het Onder-Paleozoicum in de Markvallei (Massief van Brabant). Unpublished M.Sc.-thesis, University of Gent, 72 p.

MARQUES, F.G. \& COBBOLD, P.R., 1995. Development of highly non-cylindrical folds around rigid ellipsoidal inclusions in bulk simple shear regimes: natural examples and experimental modelling. Journal of Structural Geology, 17: 589-602.

MIES, J.W., 1993. Structural analysis of sheath folds in the Sylacauga Marble Group, Talladega slate belt, southern Appalachians. Journal of Structural Geology, 15: 983-993.

PARASNIS, D.S., 1975. Methods in geochemistry and geophysics 3: Mining geophysics, 395 p., Elsevier, Amsterdam.

PARIS, F., 1996. Chitinozoan biostratigraphy and palaeoecology; in: Jansonius, J. \& McGregor, D.C. (ed.), palynology: principles and applications; American Association of Stratigraphic Palynologists Foundation, Vol. 2, p. 531-552.

PARK, A.F., 1988. Geometry of sheath folds and related fabrics at the Luikonlahti mine, Svecokarelides, eastern Finland. Journal of Structural Geology, 10: 487-498.

PIESSENS, K., VIAENE, W. \& MUCHEZ, P., 1998. Laboratoriumstudie van boorkernen in het Massief van Brabant. Unpublished ANRE-eindrapport project VLA96-3.6, $96 \mathrm{p}$.

PRICE, N.J. \& COSGROVE, J.W., 1990. Analysis of geological structures, 502 p., Cambridge University Press, Cambridge.

RAMSAY, J.G. \& GRAHAM, R.H., 1970. Strain variation in shear belts. Canadian Journal of Earth Sciences, 7: 786-813.

RAMSAY, J.G. \& HUBER, M.I., 1987. The techniques of modern structural geology: Volume 2: Folds and Fractures, p. 308-700, Academic Press, London.

SINTUBIN, M., 1997. Cleavage-fold relationships in the Lower Palaeozoic Brabant Massif (Belgium). Aardkundige Mededelingen, 8: 161-164.

SOPER, N.J., WEBB, B.C. \& WOODCOCK, N.H., 1987. Late Caledonian (Acadian) transpression in north-west England: timing, geometry and geotectonic significance. Proceedings of the Yorkshire Geological Society, 46: 175-192. 
STERPIN, M. \& DE VOS, W., 1996. Onderzoek naar metallische mineralisaties in de Paleozoïsche sokkel van Vlaanderen. Unpublished BNRE-eindrapport project VLA/94-3.5, 47 p.

VAN GROOTEL, G., 1995. Microfossielen. Unpublished BNRE-eindrapport project VLA93-3.5.1, 36 p. VAN GROOTEL, G., VERNIERS, J., GEERKENS, B., LADURON, D., VERHAEREN, M., HERTOGEN, J. \& DE VOS, W., 1997. Timing of subsidence-related magmatism, foreland basin development, metamorphism and inversion in the Anglo-Brabant fold belt. Geological Magazine, 134: 607-616.
VANSTEELANDT, P., 1993. Een overzicht van de geologische projecten. In: VANSTEELANDT, P., MOSTAERT, F., VAN ROO, J. \& BROOTHAERS, L. (eds.). Studiedag geologische kartering en geologisch onderzoek in het Vlaamse Gewest, B.N.R.E.: 1-23, Brussel.

Manuscript received on 16.10.1998 and accepted for publication on 01.10.1999 